\title{
Manufacturing Production and Non-Agricultural Employment rate in South Africa: Time Series Analysis
}

\author{
Paul-Francois Muzindutsi, Magdeline M. Maepa \\ School of Economic Sciences, North-West University: Vaal Triangle Campus, South Africa \\ 24754293@nwu.ac.za
}

\begin{abstract}
South African is faced with a high unemployment rate; however, the country's manufacturing sector is one of the sectors that have been linked with job creation. Nevertheless, the growth in manufacturing production may not increase employment opportunities if this sector continues to shift to technology-intensive methods of production, which displace labour. This study uses a vector autoregressive (VAR) model to estimate the interaction between manufacturing production and the employment rate in South Africa from 1970 to 2013. Results revealed that both variables were stationary at the first difference and there was a long-term equilibrium relationship between the variables. In the short term, a significant positive relationship between manufacturing production and employment rate was observed. Granger causality test showed that there is a causal link from manufacturing production to the employment rate. A comparison between apartheid and post-apartheid periods showed the long-run relationship only existed in the post-apartheid period of a more open economy. Findings of this study revealed that a growth in the South African manufacturing sector is linked with employment opportunities in the short-run. However, these opportunities may be reduced by changes in technology which promote capital intensive production. As such, policy-makers should encourage policies that promote a mix of labour and capital intensive production in order to maintain these employment opportunities in the manufacturing sector.
\end{abstract}

Key words: Employment, manufacturing production, VAR model, co-integration, South Africa

\section{Introduction}

Although South Africa is regarded as the gateway to Africa, it also stands as a country with one of the highest levels of unemployment, especially amongst the youth (Meyer, 2014). Job creation is of vital importance to government, citizens and the private sector alike. The manufacturing sector plays a pivotal role in the South African economy as it is linked to job creation, which allows it to contribute directly to the overall employment rate. Compared with most developing countries, South Africa's manufacturing sector is quite well developed (Fedderkel \& Simbanegavi, 2008) and has for decades been one of the main drivers of economic growth. In the period of 1930-1960, the South African economy went through a long phase of virtually uninterrupted growth in total economic activity, and in particular the output of the manufacturing sector; however, this performance started deteriorating to negative growth in the 1980s (McCarthy, 2005). This poor performance was attributed to international trade sanctions and isolation imposed on the apartheid government, as well as poor factor utilisation. After 1994 however, productivity performance in the manufacturing sector started improving due to the abolishment of the apartheid era which then led to the removal of international trade restrictions (McCarthy, 2005).

Productivity performance can be defined as a reflection of the relative growth of factor inputs and outputs (McCarthy, 2005). Labour-intensive improvements can increase productivity in the manufacturing sector and eventually influence the overall employment rate because when labour is intensive and adequately trained it increases productivity or output per unit of labour. This increase in productivity encourage manufacturing sector to employ more labour. However, the manufacturing sector is also very capital-intensive, which has a relatively negative impact on the employment rate as it decreases the labour insensitivity of the sector leading to fewer job opportunities in the sector (Herault \& Thurlow, 2009). Other factors such as production costs and shocks, such as strikes, also play a role on the impact that productivity in the manufacturing sector has on the employment rate of South Africa. Examples of shocks in the South African economy include the current (July 2014) metal workers' strike which saw car manufacturers such as Toyota and Ford halting production and threatening to cut off thousands of jobs (Bloomberg, 2014). Due to high level of strike in October 2013, the car manufacturing companies BMW and Volkswagen threatened to stop the expansion of its production plants in the South 
Africa (Vollgraaff, 2013). Such factors are important in the determination of the impact that manufacturing production has on the employment rate, especially in a highly regulated South African labour market which is characterised by high level of strikes that may encourage firms to cut down the workforce and shift to capital intense production. It is thus important that a study on the relationship that may exist between productivity in the manufacturing sector and the employment rate in South Africa is conducted in order to determine whether improvements in the manufacturing sector should be equally aligned with growth in employment.

\section{Literature Review}

The main determinant of employment is human capital, which is the value that a given individual can add to productive capacity (Haveman et al., 2003). Human capital includes education, on-the-job training, work experience as well as other traits such as the motivation and attitude that a person has intrinsically to not only perform but also to improve his/her work ethic and productivity. Improved human capital and increased production interact in such a way that high production in economic sectors tends to create room for more job opportunities. There have been numerous debates over the years on whether a relationship between output and employment exists. Out of this debate came a number of studies that have attempted to investigate whether this relationship does exist or not. Many of these studies (Akçoraoğlu 2010; Landmann 2002; Lewis-Wren, 1986; Pehkonen; 2000; Sawtelle, 2007; Smyth, 1986; Wah, 1997) found a link between output and employment while others (Madden \& Tuckewell, 1975; Sahin, Tansel \& Berument, 2013) found that no such relationship exists between these two variables, especially in the short-run. This means that a short-run shock in overall output is not directly linked to an increase or decrease in total unemployment. Furthermore, some have argued that the rapid growth of productivity, particularly in manufacturing, has hurt workers in those industries by leading producers to shed jobs and switching to capital intensive production (Sahin et al., 2013). Critics of this point of view generally argue that while this might be true for a particular firm or industry, or might hold in the shortrun, in the longer run the level of creation or unemployment will be determined by macroeconomic policies rather than by productivity growth (Sahin et al.,2013).

Numerous studies (Akçoraoğlu, 2010; Ateşoğlu, 1993; Aydıner-Avşar \& Onaran, 2010; Landmann 2002; Lewis-Wren, 1986; Pehkonen; 2000; Smyth, 1986; Wah, 1997) produced empirical evidence supporting a relationship between manufacturing productivity and employment or unemployment. Aydıner-Avşar \& Onaran (2010) found a positive long-run relationship between the manufacturing sector's total output and employment in Turkey. Wah (1997) investigated the employment effects of output and technological progress in the Malaysian manufacturing sector and concluded that improved output in the manufacturing sector contributed to overall employment creation. Among similar studies conducted, Lewis-Wren (1986) focused on manufacturing employment in the United Kingdom (UK) and concluded that output expectations are highly significant in the prediction of employment in the manufacturing sector. Smyth (1986) and Pehkonen (2000) found that there exists a relation between the cyclical stocks that occur in the production processes of the manufacturing industries and total employment and unemployment. This was also confirmed by Landmann (2002), who found that employment and productivity are strongly and positively correlated.

However, opposing conclusions on the relationship between manufacturing output and employment have also been found in other empirical studies (Basu and Foley, 2011; Madden \& Tuckewell, 1975; Sahin, Tansel \& Berument, 2013,). Madden and Tuckewell (1975) investigated the relationship between output and employment disaggregated by sectors through the consideration of numerous sectors in the Australian economy and concluded that in most of these sectors the short-run fluctuations in output had no relation to aggregate employment. Sahin et al. (2013) investigated the relationship between output and non-agricultural employment across different sectors of economic activities and found long-run relationships; nevertheless, they did not find short-run relationships between aggregate output and nonagricultural employment. Their findings showed that there was no significant short-run relationship between manufacturing output and non-agricultural employment. Furthermore, Basu and Foley (2011) demonstrated that the relationship between employment growth and growth in goods production declined during the recovery phase of the United States of America (USA) business cycle. They emphasised that the relationship between employment and the growth in goods production sectors such as manufacturing varies with economic business cycles. 
In the South Africa context however, non-agricultural employment increased by 0.5 percent in the year to the third quarter of 2002, signalling that there exists a long-run relationship between aggregate output and non-agricultural employment in the long-run (SARB, 2003). Although growth in the South African manufacturing sector cannot realistically be relied upon to create significant amounts of jobs for millions of unemployed South Africans (Wakeford, 2004), there are no empirical studies on the link between the manufacturing production and non-agricultural employment in South Africa. Furthermore, findings from international studies show that there is no empirical consensus on the relationship between these two variables. Hence, this study aims to identify the short-run and long-run relationships between these two variables by focusing on acomparison of two major economic periods namely, the apartheid and the postapartheid period.

\section{Methodology}

Data: Data used in this study involved 178 quarterly observations from 1970 quarter1 to 2014 quarter 1. Variables that have been used are the total index of non-agricultural employment and the volume of production (output) in the manufacturing sector. Both variables were obtained from the South African Reserve Bank (SARB).

Model Specification: This study aims to estimate the interactions between manufacturing production and the employment rate, and an appropriate way of modelling these multivariate relationships is the Vector Autoregressive (VAR) model. A VAR is a multivariate model which treats simultaneous set of variables equally, in which each endogenous variable is regressed on its own lags and the lags of all other variables in a finite-order system (Sims, 1980).Thus, the VAR is a form of a starting point for different analysis such as co-integration analysis, causality test, stability test, impulse response analysis and variance decompositions (Brooks, 2002). A bivariate VAR model for this study is as follows:

$L E M P L_{t}=\sum_{i=1}^{n} \beta_{1 i} L E M P L_{t-i}+\sum_{i=1}^{n} \gamma_{1 i} L M A P R_{t-i}+e_{1 t}$ $L M A P R_{t}=\sum_{i=1}^{n} \beta_{2 i} L E M P L_{t-i}+\sum_{i=1}^{n} \gamma_{2 i} L M A P R_{t-i}+e_{2 t}$

Where: $L E M P l_{t}$ is the log of employments rate at period $t, L M A P R_{t}$ is the log of the manufacturing production at period $\mathrm{t}, \beta_{1 i}, \beta_{2 i} \gamma_{1 i}$ and $\gamma_{2 i}$ are the coefficients to be estimated; $\mathrm{e}_{1 \mathrm{t}}$ and $\mathrm{e}_{2 \mathrm{t}}$ are error termsknown as shocks in a VAR model; and $n$ is the number of lags in the VAR model.

Unit Root testing and co-integration: Before estimating a VAR model, it is important to determine whether a series is stationary, as a non-stationary series can produce spurious regressions (with significant coefficients that are valueless) (Enders, 2004). To test whether the variables were stationary, this study used Augmented Dickey-Fuller (ADF) and the Phillips-Perron (PP) unit root tests and its results were compared to the results of KPSS stationarity test to check whether they led to the same conclusions. If the variables are stationary then the normal VAR, Equation 1 and 2, is estimated. However, if both variables are found to be non-stationary then a co-integration test is used to test whether a linear combination of them is stationary (this is a long-run relationship) (Brooks, 2002:388). This study used the Johansen's co-integration test to test the long run relationship between the two variables. The Johansen's (1988 and 1991) multivariate co-integrating VAR approach for this study is as follows:(considering unrestricted VAR model)

$Z_{t}=\sum_{i=1}^{k} A_{i} Z_{t-i}+\varepsilon_{t}$

Where: $Z_{t}=\left[\begin{array}{l}L E M P l_{t} \\ L M A P R_{t}\end{array}\right]$ is column vector of observations on the log values of the employment rate and manufacturing production; and, $\varepsilon_{t}=$ a column vector of random errors which are assumed not to be auto correlated. Assuming that all variables are co-integrated the VAR model (in Equation 3) can be presented as follows:

$$
\Delta Z_{t}=\Pi Z_{t-k}+\sum_{i=1}^{k-1} \Gamma_{i} \Delta Z_{t-i}+\varepsilon_{t}, \text { for } \mathrm{k} \geq 2
$$

Where: $\Pi=-\left(I-A_{1}-A_{2}-\ldots . A_{k}\right) ;$ and, $\Gamma_{i}=-\left(A_{i+1}+A_{i+2}+\ldots+A_{k}\right), i=1, \ldots, k-1$

The matrix $\Pi$ represents constant dynamic adjustments of first difference of variables respectively to the levels, regardless of time difference (Charemza \& Deadman, 1997). Thus, using the two variables (employment rate and manufacturing production) of the VAR model of this study, the decomposition of matrices $\Pi \mathrm{Z}_{\mathrm{t}-\mathrm{k}}$, with the first difference transformation, is as follows:

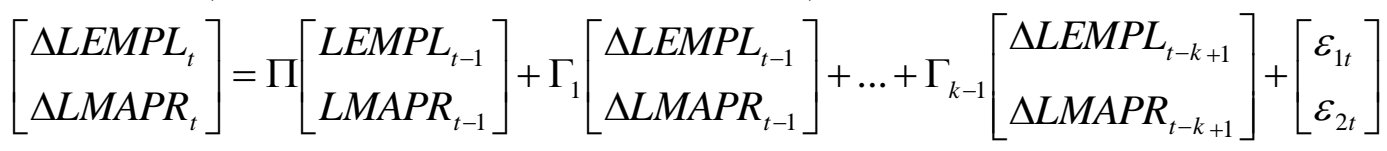


The matrix $\Pi$ (whose dimension is a 2 by 2 in this case), can be expressed as a product of two matrices (Johansen \& Juselius, 1990):

$\Pi=\alpha \beta^{\prime}$ (where $\alpha$ and $\beta^{\prime}$ are both the same since $\prod$ is a square matrix).

The matrix $\beta^{\prime}$ gives the co-integrating vectors (a matrix of long run coefficients), while $\alpha$ stand for the adjustment of parameters that shows the level of speed with which the system responds to last period's deviations from the equilibrium (Brooks, 2002). Therefore, Johansen co-integration test is based on the examination of the $\Pi$ matrix which can be interpreted as long-run coefficient matrix. The test for cointegration between EMPLt and MAPR $\mathrm{L}_{\mathrm{t}}$ is therefore calculated by looking at the rank $(\mathrm{r})$ of the $\Pi$ matrix with the use of its Eigen values and trace tests.

Vector Error Correction Model: The estimation of the short-run dynamic behaviour of the model and the long-run equilibrium relationship depends on the results from the co-integration analysis (Abdalla \& Murinde, 1997). If employment rate and the manufacturing production are not co-integrated, then the VAR model in first difference is estimated. However, if both variables are found to be co-integrated, the following Vector Error Correction Model (VECM) is estimated:

$\triangle L E M P l_{t}=\sum_{i=1}^{n} \beta_{1 i} \Delta L E M P L_{t-i}+\sum_{i=1}^{n} \gamma_{1 i} \Delta L M A P R_{t-i}+\alpha_{1} u_{1 t-1}+e_{1 t}$

$\triangle L M A P R_{t}=\sum_{i=1}^{n} \beta_{2 i} \Delta L E M P L_{t-i}+\sum_{i=1}^{n} \gamma_{2 i} \Delta L M A P R_{t-i}+\alpha_{2} u_{2 t-1}+e_{2 t}$

Where: $\mathrm{u}_{1 \mathrm{t}-1}$ and $\mu_{2 \mathrm{t}-1}$ are the error correction terms; and $\alpha_{1}$ and $\alpha_{2}$, are error correction coefficients which are expected to capture the adjustments of change in the employment rate $\left(\triangle E M P l_{t} \mathrm{t}\right)$ and change in manufacturing production $\left(\triangle M A P R_{t}\right)$ towards long-run equilibrium, while the coefficients on $\triangle E M P l_{t-i}$ and $\triangle M A P R_{t-i}$ are expected to capture the short-run dynamics of the VECM model (Abdalla \& Murinde, 1997).

Granger Causality test was also run to determine whether a one time series is useful in forecasting another (Granger, 1969). The choice of lags in the VAR Model is very critical (Li \& Liu, 2012). Thus, the number of lags $(\mathrm{k})$ will be selected based on on the comparison of six criteria for lag order selection namely, the Schwarz Information Criterion (SIC), the Hannan-Quinn Criterion (HQC), the Akaike Information Criterion (AIC), the general-to-specific sequential Likelihood Ratio test (LR), a small-sample correction to that test (SLR), and the Lagrange Multiplier (LM) test (Ivanov \& Kilian, 2005). Before interpreting VECM results, parameter stability was used to check whether the results are consistent through the period and post-apartheid periods. Other diagnostic tests such as autocorrelation, heteroscedasticity and normality tests were conducted.

\section{Results}

Results for ADF units root test and KPSSS stationarity test, in Table 1, show that manufacturing production (MAPR) is non-stationary at the level but it becomes stationary at the $1^{\text {st }}$ difference. However, the two tests produced conflicting results on unemployment at level. ADF results show that employment has no unit root (stationary) at the level while KPSS results indicate that employment is not stationary. With the $1^{\text {st }}$ difference of employment both tests agree that employment is stationary. It is therefore concluded that both variables become stationary at the $1^{\text {st }}$ difference, meaning that they have a unit root. Thus, a co-integration test is undertaken to establish whether a linear combination between these nonstationary variables exists. Before conducting the co-integration test, six criteria for lag order selection were conducted and four of them (SIC, HQC, AIC and FPE) selected 2 lags.

Table 1: Unit root and stationarity tests

\begin{tabular}{llllll}
\hline & \multicolumn{3}{c}{ Level } & \multicolumn{3}{c}{ 1st difference } \\
\cline { 2 - 6 } & & EMPL & MAPR & EMPL & MAPR \\
\hline \multirow{2}{*}{ KDF } & t-statistic & -2.977 & -1.498 & -9.568 & -11.234 \\
& P-value & 0.039 & 0.533 & 0.000 & 0.000 \\
& LM-stat. & 1.376640 & 1.562 & 0.138 & 0.273 \\
\hline
\end{tabular}

* Asymptotic critical values at the $5 \%$ level is 0.463

Results of the Johansen co-integration test, in Table 2, show that P-values of the Trace statistic and Maximum Eigen value of no co-integrating equation are less than the $5 \%$ significance level, which indicates that we reject the null hypothesis of co-integrating equation. However, the P-values of the Trace statistic and the Maximum Eigen values for at least 1 co-integrating equation are greater than the 
significance level of 5\%, which indicates that we accept the null hypothesis of at most 1 co-integrating equation. Thus, both Trace and the Maximum Eigen value tests indicate that there exists 1 co-integrating equation at the 5\% significance level. This co-integrating equation [9] shows that manufacturing production has long-run negative effect on employment rate.

Co-integration Equation: LEMPL $_{\mathrm{t}}=-0.264532 \mathrm{LMAPR}-3.493803 \mathrm{c}$

Table 2: Johansen co-integration results

\begin{tabular}{lllll}
\hline & Trace & & \multicolumn{2}{c}{ Maximum Eigen value } \\
\cline { 2 - 5 } Hypothesized No. of CE(s) & Trace statistic & P-value & Trace statistic & P-value \\
\hline None & 21.967 & 0.029 & 20.038 & 0.011 \\
At most 1 & 1.93 & 0.79 & 1.93 & 0.79 \\
\hline
\end{tabular}

Vector error correction model (VECM) results: After establishing a co-integrating relationship between manufacturing production and the employment rate, the VECM was estimated to determine the short-run disequilibrium among these two variables. Before interpreting VECM results diagnostic tests were run and they showed that there was no presence of heteroskedasticity and autocorrelation in VECM residual. However, Chow structural break test showed that long-run results were not the same in the apartheid period of closed economy and the post-apartheid period of open economy (1994-2014) and. Hence, the results of the post period were reported in this study with the discussion referring to difference of two periods in the long-run.

Table 3: VECM results

\begin{tabular}{|c|c|c|c|c|c|c|}
\hline & \multicolumn{3}{|l|}{$\triangle L E M P L O Y$} & \multicolumn{3}{|l|}{ DLMAPR } \\
\hline & Coefficient & SE & T-Stat. & Coefficient & S.E. & T-Stat. \\
\hline CointEq1 & $-0.01842^{*}$ & 0.0042 & -4.4035 & -0.02299 & 0.0125 & -1.8456 \\
\hline$\Delta$ LEMPLOY $_{\mathrm{t}-1}$ & $0.16179^{*}$ & 0.0759 & 2.1316 & $0.46897^{*}$ & 0.2261 & 2.0742 \\
\hline$\Delta$ LEMPLOY $_{\mathrm{t}-2}$ & 0.06067 & 0.0736 & 0.8245 & -0.08665 & 0.2192 & -0.3953 \\
\hline$\Delta \mathrm{LMAPR}_{\mathrm{t}-1}$ & $0.07861^{*}$ & 0.0263 & 2.9886 & 0.10915 & 0.0784 & 1.3930 \\
\hline$\Delta \mathrm{LMAPR}_{\mathrm{t}-2}$ & 0.04371 & 0.0268 & 1.6286 & 0.00089 & 0.0800 & 0.0112 \\
\hline
\end{tabular}

* Significant at the $5 \%$ level of significance

ECM results, Table 3, show that the co-integrating equation has one statistically significant Coefficient (LEMPLOY). This implies there is full adjustment towards long-run equilibrium in employment rate equation. The value of -0.01842 suggests that approximately $1.842 \%$ of deviation from equilibrium is eliminated every quarter. Short run dynamics for $\triangle$ LEMPLOY equation are positive and statistically significant at the $1^{\text {st }}$ lag. This means that the current growth in employment rate is a result of previous quarter growth in both manufacturing production and employment rate. Results also showed that previous growth in employment rate do not necessarily affect current growth manufacturing production. This is also confirmed by the results of Granger causality test, in Table 4, which shows that there is a oneway causal relationship between the two variables. In other words, employment rate does Granger cause manufacturing production but manufacturing production does not Granger cause employment rate.

Table 4: Pair wise Granger Causality Tests

\begin{tabular}{lcc}
\hline Null Hypothesis: & F-Statistic Prob. \\
\hline LMAPR does not Granger Cause LEMPLOY & 6.80539 & 0.0014 \\
LEMPLOY does not Granger Cause LMAPR & 2.22792 & 0.1109 \\
\hline
\end{tabular}

Variance Decomposition Analysis: Results for variance decomposing of employment rate, in Table 5, show that, without considering the contribution of employment, the contribution of production to the employment rate is increasing throughout the years. The maximum rate at which production contributes to the employment rate is $19 \%$ in the $15^{\text {th }}$ period. Variance decomposition analysis of manufacturing production, Table 6, indicates that, without the contribution of production itself, the contribution of employment increases gradually to $7 \%$ in the $7^{\text {th }}$ period and then begins to fall to a rate of $6 \%$ in the $15^{\text {th }}$ period. This implies manufacturing production contributes to variance in employment rate but the employment rate does not seem to have a major contribution on variance in employment. This was also confirmed by impulse response graphs (not reported in the study) analysis. Variance decomposition and 
impulse response analysis, confirm the short-run VECM results and Granger causality test which showed that manufacturing production affects employment rate in short-run.

Table 5: Variance decomposition of employment rate

\begin{tabular}{llll}
\hline Period & SE & LEMPLOY & LPRODUCT \\
\hline 1 & 0.007 & 100.000 & 0.000 \\
2 & 0.012 & 97.565 & 2.435 \\
3 & 0.015 & 94.033 & 5.967 \\
4 & 0.019 & 91.599 & 8.401 \\
5 & 0.022 & 89.787 & 10.213 \\
6 & 0.024 & 88.381 & 11.619 \\
7 & 0.026 & 87.226 & 12.774 \\
8 & 0.028 & 86.229 & 13.771 \\
9 & 0.030 & 85.335 & 14.665 \\
10 & 0.032 & 84.507 & 15.493 \\
11 & 0.034 & 83.726 & 16.274 \\
12 & 0.035 & 82.977 & 17.023 \\
13 & 0.036 & 82.249 & 17.751 \\
14 & 0.038 & 81.539 & 18.462 \\
15 & 0.039 & 80.836 & 19.164 \\
\hline
\end{tabular}

Table 6: Variance decomposition of manufacturing production

\begin{tabular}{llll}
\hline Period & SE & LEMPLOY & LPRODUCT \\
\hline 1 & 0.022 & 2.899 & 97.101 \\
2 & 0.033 & 6.212 & 93.788 \\
3 & 0.042 & 7.079 & 92.920 \\
4 & 0.050 & 7.463 & 92.537 \\
5 & 0.057 & 7.587 & 92.413 \\
6 & 0.063 & 7.566 & 92.434 \\
7 & 0.069 & 7.463 & 92.536 \\
8 & 0.075 & 7.314 & 92.686 \\
9 & 0.079 & 7.137 & 92.863 \\
10 & 0.084 & 6.944 & 93.056 \\
11 & 0.089 & 6.742 & 93.258 \\
12 & 0.093 & 6.537 & 93.463 \\
13 & 0.097 & 6.331 & 93.669 \\
14 & 0.101 & 6.127 & 93.873 \\
15 & 0.105 & 5.925 & 94.075 \\
\hline
\end{tabular}

Discussion: Findings of these study showed that the contribution of the South African manufacturing sector to job creation change changed during the post-apartheid period of the open economy. During the period of closed economy there was no long-run relationship between employment rate and manufacturing production. In the post-apartheid period of open economy, however, manufacturing production had long-run negative effect on employment. This implies that in the long-run a growth in manufacturing production will lead to a decline in employment. These findings are similar to those from the previous study by Sahin et al. (2013) which showed that the rapid growth in manufacturing production was associated with a decline in employment rate because producers had to shed jobs as they switched to capital intensive production. Contrary to findings of these study Aydıner-Avşar \& Onaran 
(2010) find a positive long-run relationship between the manufacturing sector's total output and employment in Turkey.

Findings of this study mean that, in the long-run, a large number of jobs are destroyed in the South African manufacturing sector due to adoption of technology and capital-intensive production. However, one cannot link this negative long-run relationship between South African manufacturing production and the employment rate to technological progress. For example, a study by Wah (1997) concluded that improved output in the Malaysian manufacturing sector, due technological progress, contributed to the overall employment creation. Furthermore, Sahin et al. (2013) insists that the long-run the level of job creation is determined by macroeconomic policies rather than by productivity growth. Thus, these findings may be explained by the volatile South African labour market which is highly affected by labour union strikes on a yearly basis. Thus, economic condition such as the highly unionised labour market may explain why South African manufacturing firms tend to minimise the level of labour input in the long-run.

Short-run results were similar in both periods of open and closed economy. It was revealed that growth in manufacture sector tend to increase that overall employment rate. This implies that short-run increase in manufacturing output is associated with job creation. This is in line with the economic theory of production which states that in short run, firms are able to increase their labour along with output. These short-run results are similar to those from previous studies (Lewis-Wren, 1986; Pehkonen, 2000; Smyth, 1986) which found that the employment rate and manufacturing production were positively related in the short-run. Contrary to the findings of this study Sahin et al. (2013) concluded that there was no significant short-run relationship between manufacturing output and non-agricultural employment. Furthermore, Basu and Foley (2011) demonstrated that the short-run relationship between employment and USA manufacturing production was not consistent; while Madden and Tuckewell (1975) concluded that the short-run fluctuations in manufacturing output had no effect on aggregate employment in the Australian economy.

\section{Conclusion}

The growth in the manufacturing production may not increase employment opportunities if this sector is shifting to technology-intensive methods of production which displace labour. This study investigated the relationship between manufacturing production and the non-agricultural employment rate in South Africa.Findings revealed that there is a link between the growth in the manufacturing sector and nonagricultural employment in the South African economy. In the short-run, the growth in manufacturing output is directly linked to an increase in total employment rate. In the long-run, growth in manufacturing output tends to be linked with the reduction of the number of employment opportunities in the country. Thus, the South African manufacturing sector tends to be very capital and technology-intensive in the long-run. A comparison between apartheid and post-apartheid periods showed the long-run relationship only existed in the post-apartheid period of more open economy. Overall, findings of this study revealed that a growth in the South African manufacturing sector is linked with employment opportunities in short-run. However, these opportunities may be reduced by changes in technology which promote capital intensive production. Additionally, the highly regulated South African labour market which is characterised by high level of strikes tends to encourage manufacturing firms to cut down the workforce and shift to capital intensive production.Hence, policymakers should, together with the public and private sector, establish and encourage policies that promote the co-existence of labour and technology in production in order to maintain employment opportunities in the manufacturing sector.

\section{References}

Abdalla, I. S. A. \& Murinde, V. (1997). Exchange rate and stock price interactions in emerging financial markets: evidence on India, Korea, Pakistan and the Philippines. Applied Financial Economics, $7(1), 25-35$.

Akçoraoğlu, A. (2010).Employment, economic growth and labour market performance: The case of Turkey. Ekonomik Yaklasim, 21, 101-114.

Ateşoğlu, H. S. (1993). Manufacturing and economic growth in the United States. Applied Economics, 25, 67-69.

Aydıner-Avşar, N. \& Onaran, O. (2010). The determinants of employment: A sectoral analysis for Turkey. The Developing Economies, 48(2), 203-31. 
Basu, D. \& Foley, D. K. (2011). Dynamics of output and employment in the U.S. Economy. University of Massachusetts Amherst Political Economy Research Institute. Working Paper, 248, 1-37.

Bhuckory, K. \& Burkhardt, P. (2014). South Africa Renews Mediation Talks to End Metalworkers Strike. Bloomberg, 16 July. Retrieved 31 July 2014 from http://mobile.bloomberg.com/news/2014-0716/nissan-joins-toyota-in-shutting-south-africa-plant-amid-strike.html.

Brooks, C. (2002).Introductory Econometrics for Finance, UK: Cambridge University Press.

Charemza, W. W. \& Deadman, D. F. (1997). Econometrics Practice: General to Specific Modelling, Cointegration and Vector Autoregression (2nded), UK: Edward Elgar.

Dornbusch, R., Fischer, S. \& Startz, R. (2011). Macroeconomics (11 thed), New York, NY: McGraw Hill.

Enders, W. (2004). Applied Econometric Time Series (2 ${ }^{\text {nd }}$ Ed), United State of America: WILEY.

Fedderkel, J. \& Simbanegavi, W. (2008). South African Manufacturing Industry Structure and its Implications for Competition Policy. Working Paper, 111.

Granger, C. W. J. (1969). Investigating causal relations by econometric models and cross-spectral methods. Econometrica, 37(3), 424-438.

Haveman, R., Bershadker, A. \& Schwabish, J. (2003).Human capital in the United States from 1975 - 2000. Kalamazoo, MI: W. E. Upjohn Institute for Employment Research.

Herault, N. \& Thurlow, J. (2009). Agricultural distortions, poverty and inequality in South Africa. Agricultural Distortions Working Paper, 104.

Ivanov, V. \& Kilian, L. (2005). A practitioner's guide to lag order selection for VAR impulse response analysis. Studies in Nonlinear Dynamics and, Econometrics, 9(1), 1-36.

Johansen, S. \& Juselius, K. (1990).Maximum Likelihood Estimation and Inference on Cointegration- with Applications to the Demand for Money. Oxford Bulletin of Economics and Statistics, 52(2), 169210.

Johansen, S. (1988).Statistical Analysis of Cointegration Vectors. Journal of Economic Dynamics and Control, 12, 231-55.

Johansen, S. (1991). Estimation and hypothesis testing of cointegration vectors in Gaussian vector autoregressive models. Econometrica, 59, 1551-1580.

Landmann, O. (2002). Employment, productivity and output growth.ILO, mimeographed, 2002.

Lewis-Wren, S. (1986).An econometric model of U.K. manufacturing employment using survey data on expected output. Journal of Applied Econometrics, 1, 297-316.

Li, C. \& Liu, Z. (2012).Study on the relationship among Chinese unemployment rate, economic growth and inflation. Advances in Applied Economics and Finance, 1(1), 1-6.

Madden, G. M. \& Tuckewell, R. H. (1975). The output-employment relationship in Australian industry. Economics Record, 51, 421 - 427.

McCarthy, C. (2005). Productivity performance in developing countries, country Case Studies: South Africa. Vienna, Austria: United Nations Industrial Development Organisation.

Meyer, D. F. (2014). Job Creation, a Mission Impossible? The South African Case. Mediterranean Journal of Social Sciences, 5 (16), 65-77.

Pehkonen, J. (2000). Employment, unemployment and output growth in booms and recessions: Time series evidence from Finland, 1970-96. Journal of Applied Economics, 32, 885-890.

Sahin, A., Tansel, A. \& Berument, M. K. (2013). Output-Employment Relationship across Sectors: A LongVersus Short-run Perspective. Discussion Paper Series, 7599.

SARB (South African Reserve Bank). (2003). Quarterly Bulletin No. 227 (March).

SARB. (2014). Economic and Financial Data for South Africa. Retrieved on 10 March 2014 from http://wwwrs.resbank.co.za/webindicators/EconFinDataForSA.aspx.

Sawtelle, B. (2007).Analyzing the link between real GDP and employment: An industry sector approach. Business Economics, 42, 46-54.

Sims, C. A. (1980).Macroeconomics and reality. Econometrica, 48, 1-48.

Smyth, D. J. (1986). The cyclical response of employment to output changes: United States manufacturing industries, 1948-1983. Journal of Applied Economics, 18, 495-500.

Vollgraaff, R. (2013). BMW's Investment Embargo Threatens South African Economy. Retrieved on 18 June 2014 from http://www.bloomberg.com/news/2013-10-13/bmw-s-investment-strikethreatens-south-african-economy.html.

Wah, L. Y. (1997). Employment effects of output and technological progress in Malaysian manufacturing. Journal of Development Studies, 33, 411-420.

Wakeford, J. (2004). Productivity, wages and employment in South Africa's manufacturing sector, 1970 2002. Development Policy Research Unit Working Paper 04/85. 